\title{
Evaluation Of In Vitro Antioxidant Activity and In Vivo Hepatoprotective Activity Of Moringa Oleifera Seeds Extract Against Ethanol Induced Liver Damage In Wistar Rats
}

\author{
${ }^{1}$ Eswar Kumar K ${ }^{*},{ }^{1}$ Harsha K N, ${ }^{1}$ Shabana Shaik, ${ }^{2}$ Neelakanta Rao N, ${ }^{1}$ Giri Babu N, \\ ${ }^{I}$ Pharmacology Division, A.U. College of Pharmaceutical Sciences, Andhra University, Visakhapatnam- \\ 530 003, Andhra Pradesh, India \\ ${ }^{2}$ Rite Aid-store \# 7198, 4212 Elvis Presley Blvd, Memphis, Tennesse 38116, USA
}

\begin{abstract}
The in vitro antioxidant and in vivo hepatoprotective effects of crude ethanolic extracts of Moringa oleifera (M. oleifera) seeds were evaluated in male Wistar rats against ethanol induced liver damage in preventive and curative models. The antioxidant activity of $M$. oleifera was assayed by DPPH, hydroxyl and superoxide radical scavenging activity. The various antioxidant activities were compared to standard antioxidant, ascorbic acid. In two different set of experiments, the M. oleifera extracts (50,100 and $300 \mathrm{mg} / \mathrm{kg}$ body weight $(\mathrm{bw})$, and silymarin (100 $\mathrm{mg} / \mathrm{kg} \mathrm{bw}$ ) were administered orally in both the studies. Liver injury was induced by $40 \%$ ethanol administration (3.76 $\mathrm{gm} / \mathrm{kg}$ bw, orally) for 25 days. In the 2,2-diphenyl-1-picrylhydrazil(DPPH), hydroxyl and superoxide radical scavenging activity, the $I C_{50}$ values of ethanolic extract were $196.45 \pm 0.25,175.57 \pm 0.39$ and $213.15 \pm 0.27 \mu \mathrm{g} / \mathrm{ml}$ respectively. The level of serum aspartate aminotransferase (AST), alanine aminotransferase (ALT), alkaline phosphatase $(A L P)$ and total bilirubin were determined to assay hepatotoxicity. Ethanol administration caused severe hepatic damage in rats as evidenced by elevated serum AST, ALT, ALP and total bilirubin levels. The M. oleifera and silymarin administration prevented the toxic effect of ethanol on the above serum parameters in both preventive and curative models. The present study concludes that ethanolic extract of M. oleifera seeds has significant antioxidant and hepatoprotective activity against ethanol induced hepatotoxicity, which may be associated with its high bioactive compounds including glucosinolates, isothiocyanates, thiocarbamates, and flavonoids and antioxidant properties.
\end{abstract}

Key words: Antioxidant, Ethanol, Hepatoprotective, Moringa oleifera, Rat

\section{Introduction}

The liver is a highly sensitive organ which plays a major role in maintenance and performance of the homeostasis in our body. It is the chief organ where important processes like metabolism and detoxification take place. Thus the liver is proned to injury due to the chronic exposure to drugs, environmental toxicants and other xenobiotics ${ }^{[1]}$. The liver disorders are one of the serious health problems, throughout the world. More than 350 million people were affected with chronic hepatic infections and in India above 20,000 deaths were reported every year due to liver disorders. Hepatocellular carcinoma is one of the most common tumors in the world with over 250,000 new cases each year ${ }^{[2]}$. Ethanol is a lipid-soluble non-electrolyte, which is readily absorbed from the skin and gastrointestinal tract, diffuses briskly into circulation and dispersed evenly all the way through the body ${ }^{[3]}$. The greater part of ethanol is metabolized in the liver and individuals who get addicted to alcohol by routinely drinking 50-60 g (about 4 to 5 drinks) of ethanol per day are at risk for budding alcoholic liver disease ${ }^{[4]}$. In addition, both acute and chronic administration of ethanol causes formation of cytokines in large amounts, particularly TNF- $\alpha$ by hepatic Kupffer cells, which play a chief role in causing liver injury ${ }^{[5-7]}$. Moreover, chronic administration of ethanol results in accumulation of hepatic lipids as well as lipid peroxides which lead to autooxidation of hepatic cells either by acting as a pro-oxidant or by decreasing the antioxidant levels, thereby resulting in a noteworthy hepatotoxicity ${ }^{[8]}$. Lipid peroxidation by ethanol induces hepatic oxidative stress which has been identified to take part in a pathogenic role in Alcoholic Liver Disease (ALD) ${ }^{[9]}$.In recent days, the use of herbal natural product has increased attention among the world population. Many of the herbal supplements are claimed to assist in healthy lifestyle. Medicinally, herbal drugs have made a significant contribution for the treatment of hepatotoxicity ${ }^{[10-11]}$. Among those herbs, is Moringa oleifera Lam (MO) (Family: Moringaceae), commonly known as drumstick tree or horseradish tree. Drumstick has been claimed in traditional literature to be valuable against a wide variety of diseases. Indian Materia Medica describes the use of roots of $M$. oleifera in the treatment of a number of ailments, including asthma, gout, lumbago, rheumatism, enlarged spleen or liver and internal deep seated inflammations ${ }^{[12]}$. In recent decades, the extracts of leaves, seeds and roots of M. oleifera have been extensively studied for many potential uses including hypotensive ${ }^{[13]}$, anti-tumour ${ }^{[14]}$, 
hepatoprotective ${ }^{[15]}$, analgesic activity ${ }^{[16]}$ and antioxidant ${ }^{[17]}$. Keeping these folkloric claims and reports in view, the present study attempted to assess the possible hepatoprotective potential of the crude ethanolic seed extract of $M$. oleifera in ethanol-induced hepatotoxicity in rats.

\section{a. Plant extract, Chemical and drugs}

\section{Materials And Method:}

The crude ethanolic seed extract of $M$. oleifera was supplied by M/s. Laila Impex, Vijayawada, India. 2,2-diphenyl-1-picrylhydrazil (DPPH) were purchased from Sigma Chemical Co. (St. Louis, MO, USA). Silymarin was obtained as a gift sample from Micro Labs, Bangalore, India. Aspartate aminotransferase (AST), alanine aminotransferase (ALT), alkaline phosphatase (ALP) and bilirubin estimated kits were procured from Span Diagnostics, Surat, India. All other chemicals and reagents used were of analytical grade.

\section{b. DPPH scavenging assay}

The DPPH scavenging activity of $M$. oleifera was measured according to the method of Liu and Zhao ${ }^{[18]}$. The reaction mixture contained $2 \mathrm{ml}$ of $95 \%$ ethanol, $0.1 \mathrm{M} \mathrm{DPPH}$ and $2 \mathrm{ml}$ of the M. oleifera $(50-300 \mu \mathrm{g} / \mathrm{ml})$. The solution was incubated at $25^{\circ} \mathrm{C}$ for $15 \mathrm{~min}$, and the absorbance of $M$. oleifera was determined at $517 \mathrm{~nm}$. The antioxidant activity of $M$. oleifera extract was evaluated according to the following formula: Scavenging rate $(\%)=$

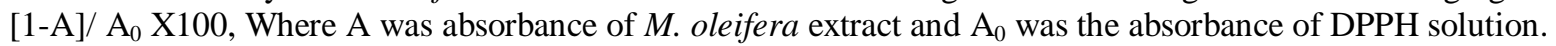

\section{c. Hydroxyl radical scavenging assay}

Hydroxyl radical scavenging activity was measured according to the method of Winter bourn and Sutton ${ }^{[19]}$. The reaction mixture contained $1 \mathrm{ml}$ of $0.15 \mathrm{M}$ phosphate buffer saline $(\mathrm{pH} \mathrm{7.4)}, 1 \mathrm{ml}$ of $40 \mathrm{~g} / \mathrm{ml} \mathrm{safranin}, 1 \mathrm{ml}$ of $0.945 \mathrm{mM}$ EDTA-Fe (II), $1 \mathrm{ml}$ of $3 \%(\mathrm{v} / \mathrm{v}) \mathrm{H}_{2} \mathrm{O}_{2}$, and $0.5 \mathrm{ml}$ of the M. oleifera $(50-300 \mu \mathrm{g} / \mathrm{ml}$ ). After incubating at $37^{\circ} \mathrm{C}$ for $30 \mathrm{~min}$, the absorbance of the M. oleifera was measured at $560 \mathrm{~nm}$. The $\mathrm{IC}_{50}$ value of M. oleifera is the effective concentration at which the hydroxyl radicals were scavenged by $50 \%$. The hydroxyl radical- scavenging activity was expressed as: Scavenging rate $(\%)=\left[\mathrm{A}_{0}-\mathrm{A}_{1}\right] / \mathrm{A}_{0} \mathrm{X} 100$, Where $\mathrm{A}_{0}$ was absorbance of blank and $\mathrm{A}_{1}$ was the absorbance of $M$. oleifera extract.

\section{d. Superoxide radical scavenging assay}

Superoxide anion radical scavenging activity was determined according to the method of Stewart and Bewley ${ }^{[20]}$. The reaction mixture $(3 \mathrm{ml})$ contained $13 \mathrm{mM}$ methionine, $10 \mathrm{mM}$ riboflavin, $75 \mathrm{M}$ nitrobluetetrazolium, $100 \mathrm{mM}$ EDTA, $50 \mathrm{mM}$ phosphate buffer $(\mathrm{pH} 7.8)$, and the M. oleifera $(50-300 \mu \mathrm{g} / \mathrm{ml})$. After illuminating the reaction mixture with a fluorescent lamp at $25^{\circ} \mathrm{C}$ for $30 \mathrm{~min}$, the absorbance of the M. oleifera was measured at $560 \mathrm{~nm}$. The scavenging rate was calculated using the following formula: Scavenging rate $(\%)=\left[\mathrm{A}_{0}-\mathrm{A}\right] / \mathrm{A}_{0} \mathrm{X} 100$, where $\mathrm{A}$ was the absorbance of $M$. oleifera and $\mathrm{A}_{0}$ was absorbance of the blank.

\section{e. Animals}

Adult male albino Wistar rats $(180 \pm 20 \mathrm{~g})$ were obtained from the Mahaveer Enterprizes, Hyderabad, India. They were kept under temperature of $(23 \pm 2)^{\circ} \mathrm{C}$, humidity of $50 \%$ and $12 \mathrm{~h}: 12 \mathrm{~h}$ of light and dark cycles, respectively. They were fed with Commercial pellet diet (Rayon's Biotechnology Pvt Ltd, India) and water was provided ad libitum. The prior approval for conducting the experiments in rats was obtained from our Institutional Animal Ethics Committee and our lab was approved by CPCSEA, Government of India (Regd. No. 516/01/A/ CPCSEA).

\section{f. In vivo Hepatoprotective Study}

\section{Preventive study:}

The rats were divided into six groups each group containing 6 rats.

Group 1: $\quad$ Normal control rats which received 2\% gum acacia for 25 days.

Group 2: $\quad$ Received $3.76 \mathrm{~g} / \mathrm{kg}$ bw of ethanol for a period of 25 days.

Group 3: $\quad$ Received $3.76 \mathrm{~g} / \mathrm{kg}$ bw of ethanol and $50 \mathrm{mg} / \mathrm{kg}$ bw of $M$. oleifera extract simultaneously for 25 days.

Group 4: $\quad$ Received $3.76 \mathrm{~g} / \mathrm{kg}$ bw of ethanol and $100 \mathrm{mg} / \mathrm{kg}$ bw of $M$. oleifera extract simultaneously for 25 days.

Group 5: $\quad$ Received $3.76 \mathrm{~g} / \mathrm{kg}$ bw of ethanol and $300 \mathrm{mg} / \mathrm{kg}$ bw of $M$. oleifera extract simultaneously for 25 days.

Group 6: $\quad$ Received $3.76 \mathrm{~g} / \mathrm{kg}$ bw of ethanol and $100 \mathrm{mg} / \mathrm{kg}$ bw of silymarin simultaneously for 25 days. Curative study: 
Group 1: $\quad$ Normal control rats which received $2 \%$ gum acacia for 50 days.

Group 2: $\quad$ Received $3.76 \mathrm{~g} / \mathrm{kg}$ bw of ethanol for a period of 50 days.

Group 3: $\quad$ Received $3.76 \mathrm{~g} / \mathrm{kg}$ bw of ethanol daily for a period of 25 days and then received $50 \mathrm{mg} / \mathrm{kg}$ bw of $M$. oleifera extract for next 25 days.

Group 4: $\quad$ Received $3.76 \mathrm{~g} / \mathrm{kg}$ bw of ethanol daily for a period of 25 days and then received $100 \mathrm{mg} / \mathrm{kg}$ bw of M. oleifera extract for next 25days.

Group 5: $\quad$ Received $3.76 \mathrm{~g} / \mathrm{kg}$ bw of ethanol daily for a period of 25 days and then received $300 \mathrm{mg} / \mathrm{kg}$ bwof M. oleifera extract for next 25 days.

Group 6: $\quad$ Received $3.76 \mathrm{~g} / \mathrm{kg}$ bw of ethanol for 25 days and then silymarin $100 \mathrm{mg} / \mathrm{kg}$ orally for next 25 days. Administrations were done orally. Silimarin was the reference hepatoprotective agent. In preventive study, blood samples were collected on $0^{\text {th }}$ and $26^{\text {th }}$ day and in curative study, blood samples were collected on $0^{\text {th }}, 26^{\text {th }}$ and $51^{\text {st }}$ day from rats retro-orbital plexus. Blood samples were collected into centrifuge tubes and were centrifuged at $3000 \mathrm{rpm}$ for $30 \mathrm{~min}$ to obtain the serum, used for the analysis of aspartate aminotransferase (AST), alanine aminotransferase (ALT), alkaline phosphatase (ALP) and total bilirubin in Semi-auto analyzer (Screen master-3000).

\section{g. $\quad$ Effect of $M$. oleifera against the DPPH radicals}

\section{Results}

The various concentrations of $M$. oleifera and standard ascorbic acid in the dose range of 50- $300 \mu \mathrm{g} / \mathrm{ml}$ showed antioxidant activity in a dose dependent manner. The $\mathrm{IC}_{50}$ values for $M$. oleifera and ascorbic acid were found to be $196.45 \mu \mathrm{g} / \mathrm{ml}$ and $148.95 \mu \mathrm{g} / \mathrm{ml}$ respectively.

\section{h. $\quad$ Effect of $M$. oleifera against the hydroxyl radicals}

The various concentrations of $M$. oleifera and standard ascorbic acid in the dose range of $50-300 \mu \mathrm{g} / \mathrm{ml}$ showed antioxidant activity in a dose dependent manner. The $\mathrm{IC}_{50}$ values for $M$. oleifera and ascorbic acid were found to be $175.57 \mu \mathrm{g} / \mathrm{ml}$ and $143.95 \mu \mathrm{g} / \mathrm{ml}$ respectively.

\section{i. $\quad$ Effect of M. oleifera on the superoxide scavenging activity}

The various concentrations of $M$. oleifera and standard ascorbic acid in the dose range of 50- $300 \mu \mathrm{g} / \mathrm{ml}$ showed antioxidant activity in a dose dependent manner. The $\mathrm{IC}_{50}$ values for $M$. oleifera and ascorbic acid were found to be $213.15 \mu \mathrm{g} / \mathrm{ml}$ and $139.08 \mu \mathrm{g} / \mathrm{ml}$ respectively.

\section{j. $\quad$ Estimation of serum biochemical parameters}

Results presented in Table 1 to 4 indicate that the levels of serum enzymes namely AST, ALT, ALP and total bilirubin levels were significantly $(\mathrm{p}<0.01)$ increased in ethanol treated rats when compared with normal rats. However, treatments of rats with M. oleifera and silymarin serum enzymes like AST, ALT, ALP and total bilirubin levels were significantly $(\mathrm{p}<0.01)$ decreased when compared to ethanol treated rats in both preventive and curative study.

\section{Discussion}

Ethanol is a chief ingredient in most of the syrups, tinctures, and other medicines. In small doses it is having a great medicinal value. But we know that most of the people in our society abuse ethanol ${ }^{[4]}$. In excess doses, it causes severe hepatic damage in humans and experimental animals. Chronic administration of ethanol is known to have a profound effect on metabolism of lipids and lipoproteins. Moreover, this results in accumulation of hepatic lipids as well as lipid peroxides which lead to autooxidation of hepatic cells by disrupting the balance between the levels of pro-oxidants and antioxidants ${ }^{[6-7]}$. Therefore, this leads to oxidative stress in the hepatic cells which is the most striking initial manifestation of alcohol induced liver injury. When there is damage to the liver cell membrane, the cytosolic enzymes are leaked into the blood stream ${ }^{[21]}$. Therefore, the elevation of these cytosolic enzymes in the blood stream is a needful quantitative marker of the extent of hepatic damage. The elevated levels of the ASP, ALT, ALP and total bilirubin levels in the rats administered with ethanol indicate the hepatocellular damage and alterations in the membrane permeability. Our reports on these elevated levels during ethanol induced hepatic damage are in accordance with the previous reports ${ }^{[22]}$. Pre-treatment and after-treatment with the $M$. oliefera attenuated the elevated levels of ASP, ALT, ALP and total bilirubin levels.Earlier studies demonstrated that root and flower of M. oleifera had reduced elevated AST, ALT and ALP levels in rodents ${ }^{[15,23]}$. And also another study has showed that leaf extracts of $M$. oleifera had significantly restored the elevated AST, ALT and ALP enzyme levels to the normal levels ${ }^{[23]}$. Recently Nadro et al. ${ }^{[24]}$ has demonstrated that $M$. oleifera leaves protect the hepatocytes by preventing the release of these 3 enzymes. Our results are consistent with earlier studies, which strongly suggest that $M$. oleifera may protect the structural integrity of hepatocytes and prevent the release of cytosolic enzymes into bloodstream. Additionally, $M$. oleifera showed effective DPPH, hydroxyl, super oxide radical scavenging activity, suggesting that it could reduce the 
oxidative stress induced by chronic administration of ethanol. This finding is consistent with previous studies which demonstrated the antioxidant activity of $M$. oleifera extract ${ }^{[17]}$. The antioxidant property of $M$. oleifera may be due to bioactive compounds glucosinolates, isothiocyanates, thiocarbamates, and flavonoids in seeds ${ }^{[26]}$.These compounds quench ROS and regenerate membrane-bound antioxidants levels during administration of M. oleifera at different dose levels in preventive and curative studies.

\section{Conclusion}

The present study concludes that the ethanolic seed extract of $M$. oleifera possesses antioxidant activity and shows a protective effect against ethanol induced hepatotoxicity in experimental rats. However, further investigation is in process on the seeds extract to identify the active constituents' responsibility for hepatoprotection.

\section{Acknowledgements}

The authors thank M/s. Lailaimpex, Vijayawada, India for providing gift sample of ethanolic seed extract of Moringa oleifera plant extract.

\section{References}

[1] Amacher, DE. A Toxicologist's Guide To Biomarkers Of Hepatic Response. Hum Exp Toxicol, 21(5), 2002; 253-262.

[2] Salhab, M And Canelo, R. An Overview Of Evidence-Based Management Of Hepatocellular Carcinoma: A Meta-Analysis. J Cancer Res Ther, 7(4), 2011; 463-475.

[3] Mcdonough, KH. Antioxidant Nutrients And Alcohol. Toxicology, 189, 2003; 89-97.

[4] Zakhari, S And Li, TK. Determinants Of Alcohol Use And Abuse: Impact Of Quantity And Frequency Patterns On Liver Disease. Hepatology, 46, 2007; 2032-2039.

[5] Thurman, RG. Alcoholic Liver Injury Involves Activation Of Kupffer Cells By Endotoxin. American Journal Of Physiology, 275, 1998; 605-611.

[6] Tsukamoto, H. Takei, Y. Mcclain, CJ. Shimizu, H. Sato, N And Thurman R. How Is The Liver Primed Or Sensitized For Alcoholic Liver Disease. Alcohol Clinical Express Research, 25, 2001; 171-181.

[7] Zhou, Z. Wang, L. Song, Z. Lambert, JC. Mcclain, CJ And Kang YJ. A Critical Involvement Of Oxidative Stress In Acute Alcohol-Induced Hepatic TNF-Alpha Production. American Journal Of Pathology, 163, 2003; 1137-1146.

[8] Crawford, DW And Blankenhorn, DH. Arterial Wall Oxygenation, Oxyradicals And Atherosclerosis. Atherosclerosis, 89, 1991; 97-108.

[9] Bunout, D. Nutritional And Metabolic Effects Of Alcoholism: Their Relationship With Alcoholic Liver Disease. Nutrition, 15, 1999; 583-589.

[10] Li, R. Guo, W. Fu, Z. Ding, G. Zou, Y And Wang Z. Hepatoprotective Action Of Radix Paeoniae Rubra Aqueous Extract Against Cc14-Induced Hepatic Damage. Molecules, 16(10), 2011; 8684-8694.

[11] Yen, FL. Wu, TH. Lin, LT And Lin, CC. Hepatoprotective And Antioxidant Effects Of Cuscuta Chinensis Against Acetaminophen-Induced Hepatotoxicity In Rats. J. Ethnopharmacol, 111, 2007; 123-128.

[12] L.J. Fuglie, The Miracle Tree. Moringa Oleifera: Natural Nutrition For The Tropics, Church World Service, Dakar, Senegal,1999, 63.

[13] Faizi, S. Siddiqui, BS. Saleem, R. Siddiqui, S. Aftab, K And Gilani, AH. Fully Acetylated Carbamate And Hypotensive Thiocarbamate Glycosides From Moringa Oleifera.Phytochemistry, 38(4),1995; 957-963.

[14] Guevara, AP. Vargas, C, Sakurai, H, Fujiwara, Y, Hashimoto, K And Maoka, T, Et Al. An Antitumor Promoter From Moringa Oleiferalam. Mutatant Research, 440, 1999; 181-188.

[15] Al-Said, MS. Mothana, RA. Al-Yahya, MA. Al-Blowi, AS. Al-Sohaibani, M. Ahmed, AF And Rafatullah, S. Edible Oils For Liver Protection: Hepatoprotective Potentiality Of Moringa Oleifera Seed Oil Against Chemical-Induced Hepatitis In Rats. J Food Sci, 77(7), 2012; T124-130.

[16] CV. Rao, And SK. Ojha, Analgeslc Effect Of Moringa Oleifera Lam Leaf Extract On Rats. $2^{\text {nd }}$ World Congress On Biotechnological Developments Of Herbal Medicine Lucknow. India. NBRI 2003. P 42.MAPA - 02-911.

[17] Santos, AF. Argolo, AC. Paiva, PM And Coelho LC. Antioxidant Activity Of Moringa Oleifera Tissue Extracts. Phytother Res, 26(9), 2012; 1366-1370.

[18] Liu, X And Zhao, M. Antioxidant Activities And Functional Composition Content Of Selected Phyllanthusemblica Fruits Juice. Food Fermentation Industries, 5: 2006; 151-154.

[19] Winterbourn, CC And Sutton, HC. Hydroxyl Radical Production From Hydrogen Peroxide And Enzymatically Generated Paraquat Radicals: Catalytic Requirements And Oxygen Dependence. Arch. Biochem. Biophys, 235, 1984; 116-126.

[20] Stewart, RC And Bewley, JD. Lipid Peroxidation Associated With Accelerated Aging Of Soybean Axes. Plant Physiol, 65(2), 1980; 245-248.

[21] Ramaiah, SK. A Toxicologist Guide To The Diagnostic Interpretation Of Hepatic Biochemical Parameters. Food Chem. Toxicol, 45 (4), 2007; 1551-1557.

[22] Sridevi, VK. Chouhan, HS. Singh, NK And Singh SK. Antioxidant And Hepatoprotective Effects Of Ethanol Extract Of Vitex Glabrata On Carbon Tetrachloride-Induced Liver Damage In Rats. Nat Prod Res, 26(12), 2012; 1135-1140.

[23] Buraimoh, AA. Bako, IG And Ibrahim, FB. Hepatoprotective Effect Of Ethanolic Leave Extract Of Moringa Oleifera On The Histology Of Paracetamol Induced Liver Damage In Wistar Rat. International Journal Of Animal And Veterinary Advances, 3(1), 2011; 10 -13.

[24] Nadro, MS. Arungbemi, RM And Dahiru, D. Evaluation Of Moringa Oleifera Leaf Extract On Alcohol-Induced Hepatotoxicity. Trop. J. Pharmaceut. Res, 5(1), 2005; 539-544. 
Table 1: Effect of M. oleifera ethanolic seeds extract and silymarin on AST and ALT on ethanol induced hepatotoxicity in wistar rats (preventive study)

\begin{tabular}{|c|c|c|c|c|}
\hline Groups & & & & \\
\hline & O day & $26^{\text {th }}$ day & O day & $26^{\text {th }}$ day \\
\hline Normal control rats & $36.5^{\mathrm{ns}} \pm 3.6$ & $37.4^{\mathrm{ns}} \pm 3.1$ & $32.6^{\mathrm{ns}} \pm 3.2$ & $33.6^{\mathrm{ns}} \pm 4.2$ \\
\hline ETH control $(3.76 \mathrm{~g} / \mathrm{kg}$ bw $)$ & $40.6^{\mathrm{ns}} \pm 4.5$ & $195.5^{\#} \pm 5.6$ & $36.4^{\mathrm{ns}} \pm 3.6$ & $150.2^{\#} \pm 5.7$ \\
\hline $\begin{array}{l}\text { ETH }(3.76 \mathrm{~g} / \mathrm{kg} \mathrm{bw})+ \\
\text { M.O }(50 \mathrm{mg} / \mathrm{kg} \mathrm{bw})\end{array}$ & $48.5^{\mathrm{ns}} \pm 2.1$ & $143.4^{*} \pm 2.5$ & $32.6^{\mathrm{ns}} \pm 3.2$ & $82.8^{*} \pm 2.9$ \\
\hline $\begin{array}{l}\text { ETH }(3.76 \mathrm{~g} / \mathrm{kg} \mathrm{bw})+ \\
\text { M.O }(100 \mathrm{mg} / \mathrm{kg} \mathrm{bw})\end{array}$ & $46.8^{\mathrm{ns}} \pm 4.3$ & $119.4^{*} \pm 4.6$ & $28.5^{\mathrm{ns}} \pm 2.5$ & $62.2^{*} \pm 2.2$ \\
\hline $\begin{array}{l}\text { ETH }(3.76 \mathrm{~g} / \mathrm{kg} \mathrm{bw})+ \\
\text { M.O (300 mg/kg bw) }\end{array}$ & $43.6^{\mathrm{ns}} \pm 3.5$ & $92.7^{*} \pm 3.1$ & $30.1^{\mathrm{ns}} \pm 5.2$ & $49.8^{*} \pm 3.7$ \\
\hline $\begin{array}{l}\text { ETH }(3.76 \mathrm{~g} / \mathrm{kg} \mathrm{bw})+ \\
\text { silymarin }(100 \mathrm{mg} / \mathrm{kg} \text { bw })\end{array}$ & $32.7^{\mathrm{ns}} \pm 3.2$ & $45.6^{*} \pm 2.5$ & $33.6^{\mathrm{ns}} \pm 4.1$ & $53.6^{*} \pm 4.2$ \\
\hline
\end{tabular}

Values are expressed as Mean \pm SD of 6 individuals. $\mathrm{ns}=$ non significant; $\mathrm{ETH}=\mathrm{Ethanol} ; \mathrm{M} . \mathrm{O}=$ M. oleifera $\# \mathrm{P}<0.01$, compared with normal control $* \mathrm{P}<0.01$, compared with ETH control

Table 2: Effect of M. oleifera ethanolic seeds extract and silymarin on ALP and total bilirubin on ethanol induced hepatotoxicity in wistar rats (preventive study)

\begin{tabular}{lcccc}
\hline Groups & \multicolumn{2}{c}{ ALP } & \multicolumn{2}{c}{ Total bilirubin } \\
\hline & 0 day & $\mathbf{2 6}^{\text {th }}$ day & 0 day & $\mathbf{2 6}^{\text {th }}$ day \\
\hline Normal control rats & $46.8^{\mathrm{ns}} \pm 4.2$ & $48.3^{\mathrm{ns}} \pm 3.8$ & $0.41^{\mathrm{ns}} \pm 0.01$ & $0.42^{\mathrm{ns}} \pm 0.02$ \\
ETH control $(3.76 \mathrm{~g} / \mathrm{kg} \mathrm{bw})$ & $43.2^{\mathrm{ns}} \pm 4.8$ & $229.6^{\#} \pm 5.4$ & $0.52^{\mathrm{ns}} \pm 0.03$ & $3.12^{\#} \pm 0.06$ \\
$\begin{array}{l}\text { ETH }(3.76 \mathrm{~g} / \mathrm{kg} \mathrm{bw})+ \\
\text { M.O }(50 \mathrm{mg} / \mathrm{kg} \mathrm{bw})\end{array}$ & $48.7^{\mathrm{ns}} \pm 5.1$ & $217.8^{*} \pm 6.2$ & $0.51^{\mathrm{ns}} \pm 0.06$ & $1.13^{*} \pm 0.03$ \\
$\begin{array}{l}\text { ETH }(3.76 \mathrm{~g} / \mathrm{kg} \mathrm{bw})+ \\
\text { M.O }(100 \mathrm{mg} / \mathrm{kg} \mathrm{bw})\end{array}$ & $50.8^{\mathrm{ns}} \pm 2.9$ & $191.8^{*} \pm 2.8$ & $0.58^{\mathrm{ns}} \pm 0.03$ & $0.94^{*} \pm 0.01$ \\
$\begin{array}{l}\text { ETH }(3.76 \mathrm{~g} / \mathrm{kg} \mathrm{bw})+ \\
\text { M.O }(300 \mathrm{mg} / \mathrm{kg} \mathrm{bw})\end{array}$ & $52.4^{\mathrm{ns}} \pm 4.2$ & $162.8^{*} \pm 2.5$ & $0.54^{\mathrm{ns}} \pm 0.04$ & $0.78^{*} \pm 0.02$ \\
$\begin{array}{l}\text { ETH }(3.76 \mathrm{~g} / \mathrm{kg} \mathrm{bw})+ \\
\text { silymarin }(100 \mathrm{mg} / \mathrm{kg} \mathrm{bw})\end{array}$ & $48.5^{\mathrm{ns}} \pm 3.5$ & $96.7^{*} \pm 3.4$ & $0.43^{\mathrm{ns}} \pm 0.01$ & $0.75^{*} \pm 0.01$ \\
\hline
\end{tabular}

Values are expressed as Mean \pm SD of 6 individuals. $\mathrm{ns}=$ non significant; $\mathrm{ETH}=\mathrm{Ethanol} ; \mathrm{M} . \mathrm{O}=$ M. oleifera $\# \mathrm{P}<0.01$, compared with normal control $* \mathrm{P}<0.01$, compared with ETH control 
Table 3: Effect of M. oleifera ethanolic seeds extract and silymarin on AST and ALT on ethanol induced hepatotoxicity in wistar rats (curative study)

\begin{tabular}{lcccccc}
\hline Groups & \multicolumn{1}{c}{ AST } & \multicolumn{1}{c}{ ALT } \\
\hline & $\mathbf{0 ~ d a y}$ & $\mathbf{2 6}^{\text {th }}$ day & $\mathbf{5 1}^{\text {st }}$ day & $\mathbf{0 ~ d a y}$ & $\mathbf{2 6}^{\text {th }}$ day & $\mathbf{5 1}^{\text {st }}$ day \\
\hline Normal control rats & $32.4^{\mathrm{ns}} \pm 3.6$ & $33.5^{\mathrm{ns}} \pm 3.2$ & $34.6^{\mathrm{ns}} \pm 3.5$ & $34.8^{\mathrm{ns}} \pm 2.9$ & $39.4^{\mathrm{ns}} \pm 4.4$ & $40.3^{\mathrm{ns}} \pm 3.2$ \\
ETH control $(3.76 \mathrm{~g} / \mathrm{kg} \mathrm{bw})$ & $32.6^{\mathrm{ns}} \pm 3.1$ & $205.8^{\#} \pm 2.8$ & $301.2^{\#} \pm 2.1$ & $30.5^{\mathrm{ns}} \pm 3.9$ & $162.5^{\#} \pm 8.4$ & $365.4^{\#} \pm 9.3$ \\
$\begin{array}{l}\text { ETH }(3.76 \mathrm{~g} / \mathrm{kg} \mathrm{bw})+ \\
\text { M.O }(50 \mathrm{mg} / \mathrm{kg} \mathrm{bw})\end{array}$ & $40.5^{\mathrm{ns}} \pm 2.2$ & $188.6^{*} \pm 2.5$ & $198.4^{*} \pm 1.8$ & $32.8^{\mathrm{ns}} \pm 2.6$ & $126.2^{*} \pm 3.9$ & $271.6^{*} \pm 3.9$ \\
$\begin{array}{l}\text { ETH }(3.76 \mathrm{~g} / \mathrm{kg} \mathrm{bw})+ \\
\text { M.O }(100 \mathrm{mg} / \mathrm{kg} \text { bw })\end{array}$ & $42.6^{\mathrm{ns}} \pm 4.2$ & $157.4^{*} \pm 6.4$ & $114.7^{*} \pm 2.7$ & $33.5^{\mathrm{ns}} \pm 3.5$ & $107.8^{*} \pm 2.4$ & $258.3^{*} \pm 2.6$ \\
$\begin{array}{l}\text { ETH }(3.76 \mathrm{~g} / \mathrm{kg} \mathrm{bw})+ \\
\text { M.O }(300 \mathrm{mg} / \mathrm{kg} \mathrm{bw})\end{array}$ & $43.7^{\mathrm{ns}} \pm 5.2$ & $106.6^{*} \pm 5.3$ & $98.6^{*} \pm 3.8$ & $26.7^{\mathrm{ns}} \pm 2.6$ & $95.3^{*} \pm 2.7$ & $242.7^{*} \pm 2.4$ \\
$\begin{array}{l}\text { ETH }(3.76 \mathrm{~g} / \mathrm{kg} \mathrm{bw})+ \\
\text { silymarin }(100 \mathrm{mg} / \mathrm{kg} \text { bw })\end{array}$ & $44.3^{\mathrm{ns}} \pm 5.8$ & $95.7^{*} \pm 5.9$ & $45.3^{*} \pm 2.3$ & $28.5^{\mathrm{ns}} \pm 1.5$ & $63.5^{*} \pm 7.4$ & $140.8^{*} \pm 1.6$
\end{tabular}

Values are expressed as Mean \pm SD of 6 individuals.

$\mathrm{ns}=$ non significant; $\mathrm{ETH}=\mathrm{Ethanol} ; \mathrm{M} . \mathrm{O}=$ M. oleifera

$\# \mathrm{P}<0.01$, compared with normal control

$* \mathrm{P}<0.01$, compared with ETH control

Table 4: Effect of M. oleifera ethanolic seeds extract and silymarin on ALP and total bilirubin on ethanol induced hepatotoxicity in wistar rats (curative study)

\begin{tabular}{|c|c|c|c|c|c|c|}
\hline Groups & & ALP & & & tal bilirubin & \\
\hline & O day & $26^{\text {th }}$ day & $51^{\text {st }}$ day & 0 day & $26^{\text {th }}$ day & $51^{\text {st }}$ day \\
\hline Normal control rats & $56.8^{\text {ns }} \pm 5.6$ & $58.3^{\text {ns }} \pm 2.2$ & $59.7^{\text {ns }} \pm 3.4$ & $0.5^{\mathrm{ns}} \pm 0.01$ & $0.52^{\mathrm{ns}} \pm 0.05$ & $0.56^{\mathrm{ns}} \pm 0.5$ \\
\hline ETH control (3.76 g/kg bw) & $52.2^{\mathrm{ns}} \pm 4.9$ & $240.7^{\#} \pm 11.7$ & $460.3^{\#} \pm 7.2$ & $0.6^{\mathrm{ns}} \pm 0.04$ & $3.92^{\#} \pm 0.31$ & $4.84^{\#} \pm 0.3$ \\
\hline $\begin{array}{l}\text { ETH }(3.76 \mathrm{~g} / \mathrm{kg} \mathrm{bw})+ \\
\text { M.O }(50 \mathrm{mg} / \mathrm{kg} \mathrm{bw})\end{array}$ & $58.6^{\mathrm{ns}} \pm 2.4$ & $214.3^{*} \pm 9.4$ & $310.8^{*} \pm 6.8$ & $0.63^{\text {ns }} \pm 0.03$ & $1.54^{*} \pm 0.03$ & $3.75^{*} \pm 0.2$ \\
\hline $\begin{array}{l}\text { ETH }(3.76 \mathrm{~g} / \mathrm{kg} \mathrm{bw})+ \\
\text { M.O (100 mg/kg bw) }\end{array}$ & $53.7^{\mathrm{ns}} \pm 4.8$ & $172.7^{*} \pm 7.6$ & $242.6^{*} \pm 7.3$ & $0.41^{\mathrm{ns}} \pm 0.01$ & $0.86^{*} \pm 0.08$ & $3.52^{*} \pm 0.3$ \\
\hline $\begin{array}{l}\text { ETH }(3.76 \mathrm{~g} / \mathrm{kg} \mathrm{bw})+ \\
\text { M.O (300 mg/kg bw) }\end{array}$ & $62.8^{\mathrm{ns}} \pm 3.1$ & $144.6^{*} \pm 3.7$ & $222.8^{*} \pm 2.5$ & $0.48^{\text {ns }} \pm 0.02$ & $0.62^{*} \pm 0.01$ & $3.32^{*} \pm 0.1$ \\
\hline $\begin{array}{l}\text { ETH }(3.76 \mathrm{~g} / \mathrm{kg} \mathrm{bw})+ \\
\text { silymarin }(100 \mathrm{mg} / \mathrm{kg} \text { bw })\end{array}$ & $58.5^{\mathrm{ns}} \pm 4.8$ & $112.9^{*} \pm 6.2$ & $152.7^{*} \pm 2.1$ & $0.6^{\mathrm{ns}} \pm 0.01$ & $0.53^{*} \pm 0.05$ & $3.11^{*} \pm 0.3$ \\
\hline
\end{tabular}

Values are expressed as Mean \pm SD of 6 individuals.

$\mathrm{ns}=$ non significant; $\mathrm{ETH}=$ Ethanol; $\mathrm{M} . \mathrm{O}=$ M. oleifera

$\# \mathrm{P}<0.01$, compared with normal control

$* \mathrm{P}<0.01$, compared with ETH control 